\title{
Impact of Factory Effluent and Inorganic Fertilizers on Availability of Nutrients in Lateritic Soil of Konkan
}

\author{
S. D. Zodge", U. Y. Puranik, Manoj Kumar Dev and S. B. Dodake \\ Department of Soil Science and Agril. Chemistry, Dr. Balasaheb Sawant Konkan Krishi \\ Vidyapeeth, Dapoli- 415 712, Dist. Ratnagiri, Maharashtra, India \\ *Corresponding author
}

\section{A B S T R A C T}

\section{Keywords \\ Effluent, Available soil properties, Konkan}

Article Info

Accepted:

18 May 2018

Available Online:

10 June 2018
Field experiment was conducted during Rabi season 2013-2014 at Central Experiment Station, Pangari Block, Wakawali, Dr. B.S.K.K.V. Dapoli, Dist. Ratnagiri. The objective of experiment was effect of factory effluent on available of nutrients in soil. The experiment was laid out in Randomize block design with three replication and nine treatments. The experimental soil was acidic but after application effluent it goes to the alkaline having $\mathrm{pH}$ above 7 . After application of effluent with inorganic fertilizers the availability of nutrients in soil was increased at great extent which is very necessary for plant growth and yield as compare to only recommended dose of fertilizer.

\section{Introduction}

Apart from the nutritive importance, palak is store house for many phyto-nutrients that have health promotional and disease prevention properties. Iron is one of the important trace element required by body for red blood cell production and as a co-factor for oxidationreduction enzyme, cytochrome oxidase during the cellular metabolism. Fresh leaves are rich source of several vital anti-oxidant vitamins like vitamin A and vitamin $\mathrm{C}$. Vitamin $\mathrm{A}$ is required for maintaining healthy mucus membranes and skin and is essential for normal eye-sight. This green leafy vegetable also contains good amount of many Bcomplex vitamins such as vitamin-B6 (pyridoxine), thiamin (vitamin B-1), riboflavin, folate and niacin. Folate help prevent neural tube defect in the offspring.

Under the present trend of exploitive agriculture in India, inherent soil fertility can no longer be maintained on the sustainable basis. It is said that nutrient supplying capacity of soil declines steadily under continuous and intensive cropping system. The use of optimum levels of $\mathrm{N}, \mathrm{P}$ and $\mathrm{K}$ failed to maintain yield levels probably due to increasing secondary and micronutrient deficiencies and also unfavorable alterations in the physical and chemical properties of soil. Apart from the fertility and productivity issues, use of chemical fertilizers is also becoming more and more difficult for the farmers due to their high costs and scarcity 
during peak season. Though, the lateritic soils are the best suited for spinach cultivation, extremely suffers by low yield especially due to acidic soil, deficiency of major nutrients $(\mathrm{N}$ and $\mathrm{P}$ ) and lack of affordability of farm inputs.

The use of effluent either in liquid or solid form in agriculture has been practiced in India, since the inception of the industry. In certain areas, the scarcity of water has forced the farmers to use the effluent as a substitute for irrigation water over the years. The indiscriminate disposal in the open area and near natural water bodies causes high water table and contaminate surface and ground waters making them unsuitable for use. Since the conventional methods of waste treatment are uneconomical and especially the difficulty in handling and transporting of large quantities, alternative methods like application of effluents to agricultural land is receiving increasing attention. The increasing cost of fertilizers and most essential nutrients also demand the attention as spent wash contains high amount of nutrients like nitrogen, phosphorus, potassium, calcium and sulphur. This is an important problem of the industries and challenge for the scientists how to use this resource as a source of nutrients and irrigation in crop production.

\section{Materials and Method}

The present field experiment was conducted at Research Farm of Pangari Block, Central Experiment Station, Wakawali, Dr. Balasaheb Sawant Konkan Krishi Vidyapeeth, Dapoli during Rabi, season 2013-14. The selection of site was done on the basis of suitability of land for the cultivation of Spinach. Effluent (composite sample of digester over flow) from the Saf Yeast Company Private Limited, Gane-Khadpoli, Chiplun District-Ratnagiri was collected and applied to the crop. Based on the irrigation requirement of the crop per plot quantity of effluent was calculated and applied directly to the plot before sowing and after first cutting of spinach as per the treatments. The research was conducted during Rabi, 2013-14 with all green variety of spinach where nine treatments are replicated thrice in randomize block design in lateritic soil of Konkan. The treatments were $T_{1}$ (recommended dose of fertilizers), $\mathrm{T}_{2}$ (application of effluent before sowing), $\mathrm{T}_{3}\left(\mathrm{~T}_{2}\right.$ $+100 \% \mathrm{RDF}), \mathrm{T}_{4}\left(\mathrm{~T}_{2}+50 \% \mathrm{RDF}\right), \mathrm{T}_{5}\left(\mathrm{~T}_{2}+\right.$ $25 \% \mathrm{RDF}$ ), $\mathrm{T}_{6}$ (application of effluent before sowing and after $1^{\text {st }}$ cutting), $\mathrm{T}_{7}\left(\mathrm{~T}_{6}+100 \%\right.$ $\mathrm{RDF}), \mathrm{T}_{8}\left(\mathrm{~T}_{6}+50 \% \mathrm{RDF}\right), \mathrm{T}_{9}\left(\mathrm{~T}_{6}+25 \%\right.$ $\mathrm{RDF})$. The available nutrient content was analyzed on the basis of methods of analysis of soils, plants, water and fertilizers tondon (1993).

\section{Results and Discussion}

\section{Soil reaction}

There was significant increase in soil $\mathrm{pH}$ due to application of effluent before sowing and after first cutting over RDF (i.e. no effluent treatment) (Table 1).This might be due to alkaline nature of effluent having ( $\mathrm{pH} \mathrm{8.05).}$ From $1^{\text {st }}$ to $3^{\text {rd }}$ cutting the treatment $T_{7}$ (application of effluent before sowing and after first cutting $+100 \% \mathrm{RDF}$ ) recorded significantly the highest soil $\mathrm{pH} 6.57,7.18$ and 7.10 at $1^{\text {st }}, 2^{\text {nd }}$ and $3^{\text {rd }}$ cutting, respectively as compared to RDF alone and only application of effluent. The result are agreement with those reported by Sweeney and Graetz (1991) who observed that the addition of distillery effluent, regardless of rate, raised the soil $\mathrm{pH}$, owing to the increase in soil $\mathrm{K}, \mathrm{Ca}, \mathrm{Mg}$ levels.

\section{Soil EC}

The electrical conductivity appears to increase with application of effluent before sowing and after $1^{\text {st }}$ cutting from treatments $\mathrm{T}_{6}$ to $\mathrm{T}_{9}$ at $2^{\text {nd }}$ and $3^{\text {rd }}$ cutting, while it was decreased in case of treatments $T_{1}$ to $T_{5}$ at $2^{\text {nd }}$ and $3^{\text {rd }}$ cutting 
(Table 1). This decrease may, probably due to downward movement of water and uptake of salts by the plants (Dargan et al., 1967).

\section{Organic carbon $\left(\mathrm{g} \mathrm{kg}^{-1}\right)$}

The organic carbon content in the soil continually increased from $1^{\text {st }}$ cutting to $3^{\text {rd }}$ cutting in all treatments except treatment $T_{1}$ (Table 1).

Distillery effluent is a plant extract; it contains the high organic load.

So the application of this distillery effluent significantly increased organic carbon content of the post-harvest soil (Mattiazo and Adagloria 1985; Rajukkanu et al., 1996; Kayalvizhi et al., 2001).

Effect of factory effluent and inorganic fertilizers on available of $N, P$ and Kin soil

\section{Available nitrogen $\left(\mathrm{kg} \mathrm{ha}^{-1}\right)$}

The data presented in (Table 24 and Fig. 10) indicating that available $\mathrm{N}$ in soil showed that its content varied from 370.04 to $430.01 \mathrm{~kg} \mathrm{ha}^{-}$ ${ }^{1}$ at $1^{\text {st }}$ cutting, 369.00 to $452.62 \mathrm{~kg} \mathrm{ha}^{-1}$ at $2^{\text {nd }}$ cutting and 262.14 to $466.21 \mathrm{~kg} \mathrm{ha}^{-1}$ at $3^{\text {rd }}$ cutting of spinach (Table 2).

It is observed from the data that the application of effluent and inorganic fertilizers significantly influenced the available nitrogen. Rajukkannu et al., (1996) reported that the higher available $\mathrm{N}$ in the post-harvest soil in the effluent treated plots might be due to mineralization of organic matter in soil supplied through distillery effluent.

The increase in $\mathrm{N}$ content over periods of observation may partly be due to the decomposition of effluent and split application of N. Further, the available N content of soil in all treatments decreased to a certain extent at $3^{\text {rd }}$ cutting. This may be attributed to the fact that lateritic soils are percolative in nature and there are probable $\mathrm{N}$ losses due to leaching and denitrification under field conditions.

\section{Available Phosphorous (kg ha $\left.{ }^{-1}\right)$}

The data regarding available phosphorus in soil as influenced by various treatments and time interval (Table 24 and Fig. 11), indicated that its content varied from 13.42 to $41.38 \mathrm{~kg}$ $\mathrm{ha}^{-1}$ at $1^{\text {st }}$ cutting 10.66 to $49 \mathrm{~kg} \mathrm{ha}^{-1}$ at $2^{\text {nd }}$ cutting and 6.16 to $51.87 \mathrm{~kg} \mathrm{ha}^{-1}$ at $3^{\text {rd }}$ cutting (Table 2). A perusal of the data indicated that there was increase in $\mathrm{P}$ content in soil with application of effluent and different levels of recommended fertilizers. Increase in $\mathrm{P}$ status could be attributed to the high $\mathrm{P}$ content of the effluent. Similar findings were reported by Ale Rita et al., (2008) and Devarajan and Oblisami (1995a and 1995b). Rajukkannu et al., (1996) clarified that the acidity and $\mathrm{HCO}_{3}$ of distillery spent wash had solubilized the native insoluble soil $\mathrm{P}$ and thus helped to increase the available $\mathrm{P}$.

\section{Available potassium (kg ha $\left.{ }^{-1}\right)$}

The available $\mathrm{K}_{2} \mathrm{O}$ content of the soil ranged from 251.61 to $4157.44 \mathrm{~kg} \mathrm{ha}^{-1}$ at $1^{\text {st }}$ cutting, 232.98 to $5356.52 \mathrm{~kg} \mathrm{ha}^{-1}$ at $2^{\text {nd }}$ cutting and 219.52 to $7624.96 \mathrm{~kg} \mathrm{ha}^{-1}$ at $3^{\text {rd }}$ cutting, respectively (Table 2). The application of effluent significantly affected the availability of $\mathrm{K}_{2} \mathrm{O}$ in soil.

These results corroborates with the finding of Pathak et al., (1998) who also reported the increase in soil $\mathrm{K}$ due to application of distillery effluent. Increase in $\mathrm{K}$ status could be attributed to the high $\mathrm{K}$ content of the effluent. The data noticed that the available $\mathrm{K}_{2} \mathrm{O}$ was decreased at $2^{\text {nd }}$ cutting but it was gradually increased at $3^{\text {rd }}$ cutting in all treatment except treatment $T_{1}$. 
Table.1 Effect of factory effluent and inorganic fertilizers on $\mathrm{pH}, \mathrm{EC}$ and organic carbon in soil at various cuttings of spinach

\begin{tabular}{|c|c|c|c|c|c|c|c|c|c|c|}
\hline \multirow{2}{*}{$\begin{array}{l}\text { Tr. } \\
\text { No. }\end{array}$} & \multirow[t]{2}{*}{ Treatments } & \multicolumn{3}{|c|}{ pH } & \multicolumn{3}{|c|}{$\mathrm{EC}\left(\mathrm{ds} \mathrm{m}^{-1}\right)$} & \multicolumn{3}{|c|}{$\mathrm{OC}\left(\mathrm{g} \mathrm{kg}^{-1}\right)$} \\
\hline & & $\begin{array}{c}1^{\text {st }} \\
\text { cutting }\end{array}$ & $\begin{array}{c}2^{\text {nd }} \\
\text { cutting }\end{array}$ & $\begin{array}{c}3^{\text {rd }} \\
\text { cutting }\end{array}$ & $\begin{array}{c}1^{\text {st }} \\
\text { cutting }\end{array}$ & $\begin{array}{c}2^{\text {nd }} \\
\text { cutting }\end{array}$ & $\begin{array}{c}3^{\text {rd }} \\
\text { cutting }\end{array}$ & $\begin{array}{c}1^{\text {st }} \\
\text { cutting }\end{array}$ & $\begin{array}{c}2^{\text {nd }} \\
\text { cutting }\end{array}$ & $\begin{array}{c}3^{\text {rd }} \\
\text { cutting }\end{array}$ \\
\hline $\mathrm{T}_{1}$ & $\begin{array}{l}\operatorname{RDF}(100: 50: 50 \\
\left.\mathrm{kg} \mathrm{ha}^{-1}\right)\end{array}$ & 5.65 & 5.54 & 5.38 & 0.210 & 0.167 & 0.147 & 8.70 & 7.20 & 6.90 \\
\hline $\mathbf{T}_{2}$ & $\begin{array}{l}\text { Application of } \\
\text { effluent before } \\
\text { sowing }\end{array}$ & 6.34 & 6.88 & 6.59 & 0.361 & 0.342 & 0.322 & 10.17 & 11.80 & 12.10 \\
\hline $\mathbf{T}_{\mathbf{3}}$ & $\mathrm{T}_{2}+100 \% \mathrm{RDF}$ & 6.55 & 6.74 & 6.41 & 0.381 & 0.366 & 0.344 & 13.63 & 14.20 & 15.10 \\
\hline $\mathbf{T}_{4}$ & $\mathrm{~T}_{2}+50 \% \mathrm{RDF}$ & 6.45 & 6.85 & 6.78 & 0.354 & 0.350 & 0.339 & 12.07 & 12.40 & 12.60 \\
\hline $\mathbf{T}_{\mathbf{5}}$ & $\mathrm{T}_{2}+25 \% \mathrm{RDF}$ & 6.41 & 6.82 & 6.78 & 0.343 & 0.330 & 0.319 & 9.97 & 11.00 & 11.40 \\
\hline$T_{6}$ & $\begin{array}{l}\text { Application of } \\
\text { effluent before } \\
\text { sowing and after } \\
1^{\text {st }} \text { cutting }\end{array}$ & 6.48 & 7.09 & 7.02 & 0.336 & 3.283 & 4.022 & 10.50 & 15.80 & 15.80 \\
\hline $\mathrm{T}_{7}$ & $\mathrm{~T}_{6}+100 \% \mathrm{RDF}$ & 6.57 & 7.18 & 7.10 & 0.377 & 2.806 & 3.049 & 13.33 & 17.50 & 17.70 \\
\hline $\mathbf{T}_{8}$ & $\mathrm{~T}_{6}+50 \% \mathrm{RDF}$ & 6.50 & 7.05 & 7.03 & 0.336 & 2.567 & 2.891 & 11.47 & 14.10 & 14.50 \\
\hline $\mathrm{T}_{9}$ & $\mathrm{~T}_{6}+25 \% \mathrm{RDF}$ & 6.27 & 6.92 & 6.85 & 0.333 & 1.954 & 2.749 & 10.57 & 12.80 & 13.10 \\
\hline & S.E. \pm & 0.09 & 0.11 & 0.13 & 0.014 & 0.393 & 0.408 & 0.37 & 1.35 & 0.62 \\
\hline & C.D. $(P=0.05)$ & 0.26 & 0.34 & 0.38 & 0.043 & 1.179 & 1.223 & 1.11 & 4.06 & 1.86 \\
\hline
\end{tabular}


Table.2 Effect of factory effluent and inorganic fertilizers on available N, P and $\mathrm{K}$ in soil at various cuttings of spinach

\begin{tabular}{|c|c|c|c|c|c|c|c|c|c|c|}
\hline \multirow{2}{*}{$\begin{array}{l}\text { Tr. } \\
\text { No. }\end{array}$} & \multirow[t]{2}{*}{ Treatments } & \multicolumn{3}{|c|}{$\mathbf{N}\left(\mathrm{kg} \mathrm{ha}^{-1}\right)$} & \multicolumn{3}{|c|}{$\mathbf{P}_{2} \mathbf{O}_{5}\left(\mathrm{~kg} \mathrm{ha}^{-1}\right)$} & \multicolumn{3}{|c|}{$\mathrm{K}_{2} \mathrm{O}\left(\mathrm{kg} \mathrm{ha}^{-1}\right)$} \\
\hline & & $\begin{array}{c}1^{\text {st }} \\
\text { cutting }\end{array}$ & $\begin{array}{c}2^{\text {nd }} \\
\text { cutting }\end{array}$ & $\begin{array}{c}3^{\text {rd }} \\
\text { cutting }\end{array}$ & $\begin{array}{c}1^{\text {st }} \\
\text { cutting }\end{array}$ & $\begin{array}{c}2^{\text {nd }} \\
\text { cutting }\end{array}$ & $3^{\text {rd }}$ & $\begin{array}{c}1^{\text {st }} \\
\text { cutting }\end{array}$ & $\begin{array}{l}2^{\text {nd }} \\
\text { cutting }\end{array}$ & $\begin{array}{c}3^{\text {rd }} \\
\text { cutting }\end{array}$ \\
\hline $\mathbf{T}_{1}$ & RDF (100:50:50 kg ha $\left.{ }^{-1}\right)$ & 370.04 & 369.00 & 262.14 & 13.42 & 10.66 & 6.16 & 251.61 & 232.98 & 219.52 \\
\hline $\mathbf{T}_{2}$ & $\begin{array}{l}\text { Application of effluent } \\
\text { before sowing }\end{array}$ & 391.67 & 431.72 & 375.99 & 23.05 & 29.85 & 28.62 & 3713.92 & 2186.24 & 2284.80 \\
\hline $\mathbf{T}_{3}$ & $\mathrm{~T}_{2}+100 \% \mathrm{RDF}$ & 420.53 & 445.31 & 433.18 & 26.83 & 42.96 & 32.85 & 4157.44 & 2477.44 & 3346.56 \\
\hline $\mathbf{T}_{4}$ & $\mathrm{~T}_{2}+50 \% \mathrm{RDF}$ & 406.63 & 426.82 & 421.19 & 32.06 & 33.32 & 29.69 & 3758.72 & 2325.12 & 3171.84 \\
\hline $\mathbf{T}_{5}$ & $\mathrm{~T}_{2}+25 \% \mathrm{RDF}$ & 376.98 & 424.54 & 413.67 & 29.91 & 37.59 & 28.93 & 3660.16 & 2266.88 & 2867.20 \\
\hline $\mathrm{T}_{6}$ & $\begin{array}{l}\text { Application of effluent } \\
\text { before sowing and after } 1^{\text {st }} \\
\text { cutting }\end{array}$ & 390.88 & 429.63 & 443.22 & 35.80 & 43.67 & 49.13 & 3409.28 & 4471.04 & 7423.36 \\
\hline $\mathbf{T}_{7}$ & $\mathrm{~T}_{6}+100 \% \mathrm{RDF}$ & 430.01 & 452.62 & 466.21 & 41.38 & 49.00 & 51.87 & 4130.56 & 5356.52 & 7624.96 \\
\hline $\mathrm{T}_{8}$ & $\mathrm{~T}_{6}+50 \% \mathrm{RDF}$ & 412.67 & 442.17 & 453.14 & 19.58 & 42.00 & 49.47 & 3991.68 & 5344.64 & 6773.71 \\
\hline$T_{9}$ & $\mathrm{~T}_{6}+25 \% \mathrm{RDF}$ & 375.54 & 429.63 & 442.20 & 26.69 & 40.43 & 44.73 & 3530.24 & 5187.84 & 6008.78 \\
\hline & S.E. \pm & 3.13 & 14.82 & 9.02 & 4.119 & 4.271 & 4.848 & 281.86 & 451.00 & 448.51 \\
\hline & C.D. $(P=0.05)$ & 9.38 & 44.43 & 27.05 & 12.35 & 12.81 & 14.53 & 845.02 & 1352.10 & 1344.63 \\
\hline
\end{tabular}


Table.3 Effect of factory effluent and inorganic fertilizers on exchangeable $\mathrm{Ca}$ and $\mathrm{Mg}$ and water soluble chloride in soil at various cuttings of spinach

\begin{tabular}{|c|c|c|c|c|c|c|c|c|c|c|}
\hline \multirow{2}{*}{$\begin{array}{l}\text { Tr. } \\
\text { No. }\end{array}$} & \multirow[t]{2}{*}{ Treatments } & \multicolumn{3}{|c|}{$\mathrm{Ca}\left[\mathrm{cmol}\left(\mathrm{p}^{+}\right) \mathrm{kg}^{-1}\right]$} & \multicolumn{3}{|c|}{$\operatorname{Mg}\left[\mathrm{cmol}\left(\mathrm{p}^{+}\right) \mathrm{kg}^{-1}\right]$} & \multicolumn{3}{|c|}{$\mathrm{Cl}\left(\operatorname{meq} \mathrm{L}^{-1}\right)$} \\
\hline & & $\begin{array}{c}1^{\text {st }} \\
\text { cutting }\end{array}$ & $\begin{array}{c}2^{\text {nd }} \\
\text { cutting }\end{array}$ & $\begin{array}{c}3^{\text {rd }} \\
\text { cutting }\end{array}$ & $\begin{array}{c}1^{\text {st }} \\
\text { cutting }\end{array}$ & $\begin{array}{c}2^{\text {nd }} \\
\text { cutting }\end{array}$ & $\begin{array}{c}3^{\text {rd }} \\
\text { cutting }\end{array}$ & $\begin{array}{c}1^{\text {st }} \\
\text { cutting }\end{array}$ & $\begin{array}{c}2^{\text {nd }} \\
\text { cutting }\end{array}$ & $\begin{array}{c}3^{\text {rd }} \\
\text { cutting }\end{array}$ \\
\hline$\overline{T_{1}}$ & $\operatorname{RDF}\left(100: 50: 50 \mathrm{~kg} \mathrm{ha}^{-1}\right)$ & 3.38 & 3.26 & 3.20 & 2.03 & 1.63 & 1.54 & 1.80 & 1.59 & 1.26 \\
\hline $\mathbf{T}_{2}$ & $\begin{array}{l}\text { Application of effluent before } \\
\text { sowing }\end{array}$ & 4.43 & 5.27 & 4.50 & 4.27 & 4.67 & 3.22 & 5.50 & 5.18 & 3.17 \\
\hline $\mathbf{T}_{\mathbf{3}}$ & $\mathrm{T}_{2}+100 \% \mathrm{RDF}$ & 5.00 & 5.37 & 5.00 & 5.03 & 5.63 & 4.63 & 6.17 & 5.90 & 4.17 \\
\hline $\mathbf{T}_{4}$ & $\mathrm{~T}_{2}+50 \% \mathrm{RDF}$ & 4.80 & 4.83 & 4.80 & 4.43 & 5.00 & 4.43 & 4.50 & 4.30 & 4.17 \\
\hline$T_{5}$ & $\mathrm{~T}_{2}+25 \% \mathrm{RDF}$ & 4.13 & 5.03 & 4.57 & 4.43 & 5.00 & 4.03 & 2.62 & 2.24 & 2.13 \\
\hline $\mathrm{T}_{6}$ & $\begin{array}{l}\text { Application of effluent before } \\
\text { sowing and after } 1^{\text {st }} \text { cutting }\end{array}$ & 4.70 & 6.17 & 6.53 & 4.35 & 4.90 & 5.63 & 4.73 & 20.50 & 8.00 \\
\hline $\mathbf{T}_{7}$ & $\mathrm{~T}_{6}+100 \% \mathrm{RDF}$ & 4.87 & 6.57 & 6.80 & 6.03 & 6.83 & 7.47 & 5.48 & 20.67 & 9.83 \\
\hline $\mathrm{T}_{8}$ & $\mathrm{~T}_{6}+50 \% \mathrm{RDF}$ & 4.27 & 5.80 & 6.47 & 5.10 & 6.33 & 6.13 & 3.50 & 19.67 & 8.50 \\
\hline $\mathrm{T}_{9}$ & $\mathrm{~T}_{6}+25 \% \mathrm{RDF}$ & 4.17 & 5.23 & 6.30 & 5.03 & 6.03 & 6.73 & 2.00 & 19.00 & 8.50 \\
\hline & S.E. \pm & 0.26 & 0.56 & 0.51 & 0.47 & 0.43 & 0.18 & 0.21 & 0.35 & 0.72 \\
\hline & C.D. $(P=0.05)$ & 0.78 & 1.67 & 1.52 & 1.42 & 1.27 & 0.54 & 0.63 & 1.05 & 2.16 \\
\hline
\end{tabular}


Effect of factory effluent and inorganic fertilizers on exchangeable $\mathrm{Ca}, \mathrm{Mg}$ and $\mathrm{Cl}$ in soil

\section{Exchangeable Ca $\left(\mathrm{kg}^{-1}\right)$}

The soil calcium at various cuttings ranged from 3.38 to $5.00 \mathrm{cmol}(\mathrm{p}+) \mathrm{kg}^{-1}$ at $1^{\text {st }}$ cutting, 3.26 to $6.57 \mathrm{cmol}(\mathrm{p}+) \mathrm{kg}^{-1}$ at $2^{\text {nd }}$ cutting and 3.20 to $6.80 \mathrm{cmol}(\mathrm{p}+) \mathrm{kg}^{-1}$ at $3^{\text {rd }}$ cutting (Table 3). The effluent application significantly increased the exchangeable $\mathrm{Ca}$ content of soil at all cuttings. This might be due to Ca content of the effluent (Devrajan et al., 1996; Baskar et al., 2001; Kayalvizhi et al., 2001 and Baskar et al., 2003). Devarajan and Oblisami (1995b) also reported that the available $\mathrm{Ca}$ was significantly increased with graded doses of effluent from 5.2 per cent to 54.58 per cent.

\section{Exchangeable $\mathrm{Mg}\left(\mathrm{kg}^{-1}\right)$}

The exchangeable magnesium content of soil ranged from 2.03 to $6.03 \mathrm{cmol}(\mathrm{p}+) \mathrm{kg}^{-1}$ at $1^{\text {st }}$ cutting, 1.63 to $6.83 \mathrm{cmol}^{(\mathrm{p}+) \mathrm{kg}^{-1}}$ at $2^{\text {nd }}$ cutting and 1.54 to $7.47 \mathrm{cmol}(\mathrm{p}+) \mathrm{kg}^{-1}$ at $3^{\text {rd }}$ cutting (Table 3). The data further indicated that exchangeable magnesium content of the soil increased due to two time application of effluent over RDF from treatment $\mathrm{T}_{6}$ to $\mathrm{T}_{9}$ at $2^{\text {nd }}$ and $3^{\text {rd }}$ cutting. This might be due to $\mathrm{Mg}$ content of the effluent (Baskar et al., 2003). This is in accordance with Devarajan and Oblisami (1995b) and Patil (2012) who reported that the exchangeable magnesium of the soils was significantly increased with graded effluent irrigations. In this context, Bose et al., (1980) clarified that the increase in the content of $\mathrm{Mg}$ might be the reason for the little increase in the $\mathrm{pH}$ of post-harvest soil upon effluent application. Tisdale et al., (1995) explained that organic matter increases CEC, which reduces potential leaching losses of effluent such as $\mathrm{K}^{+}, \mathrm{Ca}^{2+}$ and $\mathrm{Mg}^{2+}$ and its availability.

\section{Water soluble Chloride (meq $\mathbf{L}^{-1}$ )}

The data of water soluble chloride in soil showed that it's content varied from 1.80 to $6.17 \mathrm{meq} \mathrm{L}^{-1}$ at $1^{\text {st }}$ cutting, 1.59 to $20.67 \mathrm{meq}$ $\mathrm{L}^{-1}$ at $2^{\text {nd }}$ cutting and 1.26 to $9.83 \mathrm{meq} \mathrm{L}^{-1}$ at $3^{\text {rd }}$ cutting (Table 3 ). It is revealed that from the data the two time application of effluent significantly affected the water soluble chloride. There was significant and gradual increase in water soluble chloride content of soil with one or two time effluent application. This increase in chloride content might be due to more chloride content in the effluent.

Application of effluent with inorganic fertilizers resulted in a significant increase in soil $\mathrm{pH}, \mathrm{EC}$, organic carbon, available $\mathrm{N}, \mathrm{P}$, $\mathrm{K}, \mathrm{Ca}, \mathrm{Mg}$ and water soluble chloride contents in the soils and indicating build-up of soil fertility.

\section{References}

Ale Rita, Jha, P. K. and Belbase, N. (2008). Effect of distillery effluent on some agriculture crops. A case of environmental injustice to local farmers in khajuravdc, banke. Scientific word, 6 (6): 68-75.

Baskar, M., Kayalvizhi, C. and Subash Chandra B. M. (2003). Eco-friendly utilization of distillery effluent in agriculture. - A review. Agric. Rev. 24(1): 16-30.

Bose, S. M., Gopal, H., Baskar, M., Kayalvizhi, C. and Sivanandham, M. (2002). Utilization of distillery effluent in cost sandy soil to improve soil fertility and yield of sugarcane. Symposium no. 30, $17^{\text {th }}$ World Congress of Soil Science, 14-2 $1^{\text {th }}$ August 2002, Thailand. pp 980-1 to 1980-8.

Dargan, K. S., Gaul, BL., Abrol, I.P. and Bhumbla, D. R. (1976). Effect of Gypsum, farm yard manure and Zinc on 
the yield of berseem, rice and maize grown in a highly sodic soil. Indian $J$. agric. Sci. 46 (11): 535-541.

Devarajan, L. and Oblisami, G. (1995a). Effect of distillery effluent on soil properties, yield and quality of sugarcane. Madras Agriculture Journal 82 (5): 397-399.

Devrajan, L. and Oblisami, G. (1995b). Effect of distillery effluent on soil fertility status yield and quality of Rice. Madras. Agric. J.82 (12): 664-665.

Kayalvizhi, C. (2001). In Proceeding of National Seminar on use of poor quality water and sugar industrial effluents in agriculture. Feb. $5^{\text {th }}, 2001$. AC and RI, Trichy, pp 75.

Mattiazo, M.E. and Ada Gloria, N. (1985). Effect of vinasse on soil acidity. STAB (Portuguese) 4(2): 38-40.

Pathak, H., Joshi, H.C., Chaudhary, A., Chaudhary, R., Kalra, N. and Dwivedi, M.K. (1998).Distillery effluent as soil amendment for wheat and rice. J. Indian Soc. Soil Sci. 46 (1): 155-157.
Patil, P.V. (2012). Effect of factory effluent (Saf yeast) on growth, yield, nutrient uptake by rice and changes in soil properties. M.Sc. (Ag.)Thesis submitted to Dr. B.S. Konkan Krishi Vidyapeeth, Dapoli.

Rajukkannu, K. (1996). In Proceeding of National Seminar on use of poor quality water and sugar industrial effluents in agriculture. $28^{\text {th }}$ and $29^{\text {th }}$ October, 1996. $\mathrm{AC}$ and RI, Trichy, pp 30-39.

Sweeney, D. W. and Graetz, D. A. (1991).Application of distillery waste anaerobic digester effluent to Augustine grass. Agriculture Ecosystems and Environment33, 341-351.

Tandon, HLS. (1993). Methods of analysis of soils, plants, water and fertilizers. FAO and Consultation Organization, New Delhi.

Tisdale, L. Samuel, Werner L. Nelson, James D. Beaton and John L. Havlin (1995). Soil fertility and fertilizers published by Prentice, Hall of India Private Limited, New Delhi. p. 316, 321, 325, 335 and 336.

\section{How to cite this article:}

Zodge S. D., U. Y. Puranik, Manoj Kumar Dev and Dodake S. B. 2018. Impact of Factory Effluent and Inorganic Fertilizers on Availability of Nutrients in Lateritic Soil of Konkan. Int.J.Curr.Microbiol.App.Sci. 7(06): 1889-1896. doi: https://doi.org/10.20546/ijcmas.2018.706.224 